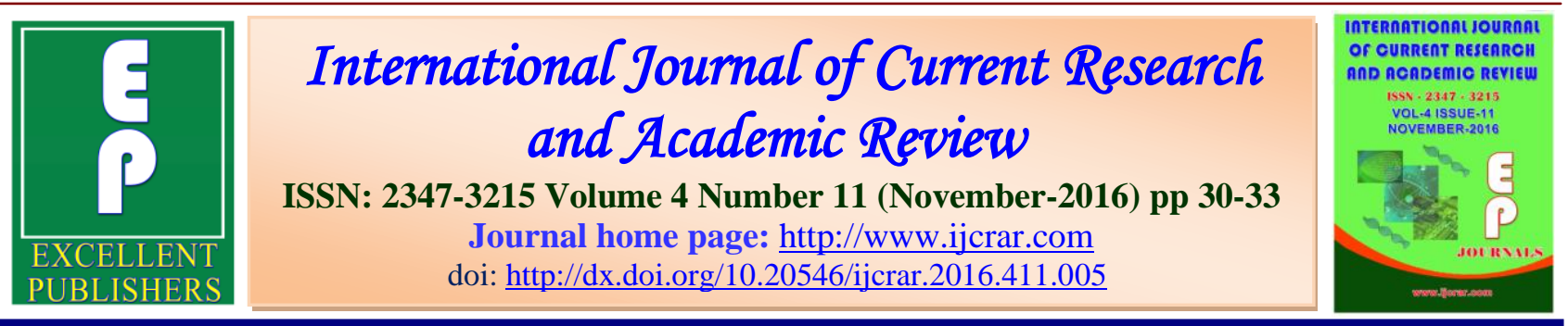

\title{
Bio-ethanol Extract from Banana (Musa acuminata) and Mango (Mangifera indica) Peelings
}

\author{
T. Anthoney Swamy* and Lasiti Timothy \\ Department of Chemistry, School of Science and Technology, University of Eastern Africa, \\ Baraton, P.O. Box 2500, Eldoret, Kenya
}

*Corresponding author

\begin{tabular}{|l|l|}
\hline \multirow{2}{*}{ KEYWORDS } & A B S T R A C T \\
\cline { 2 - 3 } $\begin{array}{l}\text { Bango, } \\
\text { bio-ethanol, } \\
\text { fermentation, } \\
\text { peelings, } \\
\text { musa acuminate, } \\
\text { magnifera indica. }\end{array}$ & $\begin{array}{l}\text { This study was conceptualized to identify whether or not the banana and } \\
\text { mango peelings will be a feasible source of bio-ethanol and to identify the } \\
\text { significant effect of the amount of bio-waste used and length of the } \\
\text { fermentation time on the net bio-ethanol yield. This study primarily aimed to } \\
\text { extract bio-ethanol from banana }(\text { Musa acuminata) and mango (Mangifera } \\
\text { indica) peelings which were subjected to the fermentation and distillation } \\
\text { process, then a significant amount of bio-ethanol can be extracted. The } \\
\text { amount of bio-ethanol yielded by banana peels was greater than that yielded } \\
\text { by the mango peelings. Both the yields showed positive results of ethanol. }\end{array}$ \\
\hline
\end{tabular}

\section{Introduction}

In recent years, a great deal of attention is being paid to the utilization of bio-ethanol from grain as alternative and eco-friendly fuel throughout the world, which would lead to food shortage and price rise of grain. Thus, there is an urgent need to develop non-polluting and renewable energy source. Bio-ethanol refers to ethanol liquid which is made from common crops including sugar cane and corn (Moukamner et al., 2010). It is considered an alternative to petroleum and diesel and its popularity is emerging as fuel for cars. The production of ethanol from sugars extracted from fruit peels as an energy supply is renewable as the non-fossil carbon source used here is readily replenished.
The banana (Musa acuminata) and mango (Mangifera indica) are one of the abundant fruits in Kenya. With the enormous amount of these fruits produced and consumed annually, huge amount of their fruit peels are thrown away as well. To resolve both the issues of waste disposal and the demand for a renewable energy source, the researchers thought of a way to make use of common household wastes, such as fruit peels, which is beneficial to both the public and the environment by using it as a source for production of bio-ethanol (Renewable Fuels Association, 2007; Satish Babu, 2010). The concept of producing bio-ethanol from banana and mango peelings came from the 
notion that banana and mango peelings have considerable amounts of glucose (Inderwildi, 2009).

The experimentation on this issue, made by "domostyl" (which holds the European patent), led to the development of a bio alcohol fireplace $13,000 \mathrm{btu}$, or $+16^{\circ}$ per hour in $70 \mathrm{~m}^{2}$. The process of bio-ethanol production generates, depending on the feedstock used, other products with economic value, for use as appropriate to the animal feed, co-generation, etc., (Lalitha Lalitha et al., 2011; Pramanik et al., 2005 ).

Bio-ethanol from sugar cane in Brazil, the yield of ethanol from sugar cane was nearly 6,000 liters per hectare, compared to 2,000 liters in 1975. Ethanol production in Brazil accounts for about $20 \%$ of the fuel economy of internal transport.

Typically, the eroei of ethanol from grain is around the value 1, the hero made in Brazil with sugar cane and is likely to exceed a value of Brazilian sources claim a 7-8 lead without rigorous proofs. According to Brazilian sources optimistic, Brazil will produce 6,000 gallons of ethanol consumes 750-860 liters per production.

Another method that allows the production of bio-ethanol is to get the first of glucose and produce ethanol by fermentation using. The trunk of the tree, usually spruce, should be properly pre-processed to obtain shredded wood, which is then subjected to cooking and therefore is the extraction of glucose. After the submition the extract from the hexose substrate for fermentation by Saccharomyces cerevisiae, or yeast organisms which operate in anaerobic conditions and giving them as a final product of the glycolytic pathway in which pyruvate is first decarboxylated to acetaldehyde and after obtaining a hydrogenation, in fact, ethanol. The ethanol produced, however, has a maximum concentration of $25-30 \%$ because the yeast has a low ability to withstand high concentrations of alcohol. For this reason it is subjected to azeotropic distillation to obtain a 94-95\% ethanol (Zhang et al., 2005).

Large amounts of cellulose are hydrolyzed and through the use of fungi or bacteria convert cellulose to glucose and other sugars, then ferment by yeast or other microbes. Innovative research is aimed at genetically modifying the bacteria, yeasts such as Saccharomyces cerevisiae modified to produce twice as much ethanol. Another avenue of research is to combine the characteristics of break down cellulose into glucose with that of turning sugar into ethanol by a single organization. Bio-ethanol from cellulose is much more expensive than that obtained from sugar cane and only major scientific advances can make it convenient. The cost is not due to raw material (cellulose), but its transformation into bio-ethanol. The current industrial processes are the cost of cellulose ethanol three times that obtained from sugar cane. The aim of the current study is to extract bio-ethanol from banana (Musa acuminata) and mango (Mangifera indica) peelings by using the fermentation and distillation process

\section{Materials and Methods}

\section{Fermentation process}

The chopped banana (one kilo gram) and mango peelings ( $11 / 2 \mathrm{~kg}$ of mangoes) were each measured and divided into 2 piles of 100 grams. Each pile was blended with $200 \mathrm{ml}$ water and then poured into a plastic bottle. $100 \mathrm{ml}$ water and 1 teaspoon of baker's yeast were added to each container 
and was sealed. The containers were labeled and stored in room temperature.

Each pile was assigned to different treatments, where:

Treatment 1: $50 \mathrm{~g}$ of banana and mango peelings were fermented for 4 days

Treatment 2: $150 \mathrm{~g}$ of banana and mango peelings were fermented for 2 days

The initial weight of each container were measured and recorded. The mass difference between the beginning of fermentation and two/four days after, of every container, will be calculated and compared.

\section{Distillation process}

All the materials needed for the study were gathered. The gathered bananas and mangoes were washed and peeled. The peelings were chopped and then pureed with the blender. About $200 \mathrm{~g}$ of banana and mango peelings were used for the entire study. The cups were then gathered after either 48 or 96 hours of fermentation. The fermented peelings were then distilled for one hour and 30 minutes. Then, the obtained ethanol was distilled again for another 30 minutes. Afterwards, the distillate was weighed and recorded. The net bio-ethanol yield of each container was measured, averaged and compared.

\section{Results and Discussion}

After two/four days of fermentation, the obtained ethanol was distilled for 1 hour and 30 minutes. Based from the results obtained from the mango and banana peels, the second treatment (higher amount of biowastes used) had a greater amount of bioethanol yield compared to the first treatment (longer fermentation time). The results showed that using higher amount of biowaste produces a greater net bio-ethanol yield. The amount of bio-ethanol yielded by banana peels was greater than that yielded by the mango peelings. Both the yields had positive results of ethanol, the products lit and they produced a blueish flame.

Bio-ethanol is ethanol produced by a process of fermentation of biomass. Agricultural products rich in sugar (carbohydrates) such as cereals, sugar crops, the starch and pomade. For energy bio-ethanol can be used as a component for gasoline or for the preparation of ethyltert-butyl ether a derivative of high octane. It can be used in gasoline in proportions of up to $20 \%$ without changing the engine, motor or pure in flex. We can use bio-ethanol as a fuel in biocamini, exploiting the power of heat to warm the room (http://www.moundtop.com).

Marketing this product commercially can be a very good and successful business, thus enhancing rural economic development. Car owners can use this product as an additive to their usual gasoline to improve its combustion efficiency. Using bio-ethanol can help reduce the amount of carbon monoxide produced by vehicles thus improving air quality. The proponents recommend to the future researchers to make use of other assorted fruits as a source for bio-ethanol extraction (Akubor et al., 2003). They may also improve the product by creating a bigger distillation system. Further research regarding other combinations and refinement of the different areas of this methodology for higher bioethanol yield, as well as the feasibility examinations and further studies about the economic technicalities of the study would as well be highly recommended.

\section{Conclusion}

Bio-ethanol can be extracted through the fermentation and distillation process from 
Int.J.Curr.Res.Aca.Rev.2016; 4(11): 30-33

the peelings of banana (Musa acuminata) and mango (Mangifera indica) using the yeast Saccharomyces cerevisiae. The findings also indicate that the amount of bioethanol produced in the group with the 96hour fermentation time is greater than the bio-ethanol produced after 48 hours, and that the group with $100 \mathrm{~g}$ of bio-waste used results to greater bio-ethanol yields compared to the group with $50 \mathrm{~g}$ of biowaste. Moreover, the researchers can conclude that the two independent variables, the fermentation time and the amount of biowaste used, have a significant effect in terms of the bio-ethanol yield obtained. Over all, these results state that the banana (Musa acuminata) and mango (Mangifera indica) peelings are potential raw material sources for bio-ethanol extraction.

\section{Acknowledgements}

The authors of this paper are very much thankful to the Department of Chemistry, University of Eastern Africa; Baraton. The authors also thank the lab assistants for their dedication to ensure the smooth contraction of this study.

\section{References}

Akubor, P.I., P.I., Adamolekun, F.O., Oba, C.O., Obari, H. and Abudu, I.O. 2003. $A O A C$., 58(3): 1.
Awe, S. 2011. Curr. Res. J. Biol. Sci., 3, 443.

Hammond, J.B., Egg, R., Diggins, D., Coble, C.G. 1996. Bio-resource Technol., 56, 125.

http://www.moundtop.com.

Inderwildi, O.R. 2009. King Energy and Environmental Sci., 2, 343.

Lalitha, G. and Rajeshwari Sivaraj. 2011. Int. J. Pharma and Bio Sci., 2(2): 15.

Moukamner, C., Kinooka, M., Sugiyama, M., Kaneko, Y., Boonchird, C., Harashma, S., Noda, H., Ninomiya, K., Shioya, S., Katakura, Y. 2010. Appl. Microbiol. Biothecnol., 88(1): 87-94.

Petersson, A., Thomsen, M.H., HauggaardNielsen, H. and Thomsen, A.B. 2007. Biomass and energy, 31,812.

Pramanik, K. and Rao, I. 2005. E. J., 85, 53.

Renewable Fuels Association. 2007. Industrial statistics.http://www. ethanolrfa.Org/ industry/statistics.

Satish Babu, R. 2010. Int. J. Biotech\& Biochem., Vol 3, 351- 357.

Wyman, E. 2001. Appl. Biochem. Biotech., 91(5), 21.

Zhang, P., Whistler, R.L., Be Miller and Hamaker, B.R. 2005. Carbohydrate polymers, 59, 443.

\section{How to cite this article:}

Anthoney Swamy, T., and Lasiti Timothy. 2016. Bio-ethanol Extract from Banana (Musa acuminata) and Mango (Mangifera indica) Peelings. Int.J.Curr.Res.Aca.Rev.4(11): 30-33. doi: http://dx.doi.org/10.20546/ijcrar.2016.411.005 